\title{
The Role of Climate and Topography in Shaping the Diversity of Plant Communities in Cabo Verde Islands
}

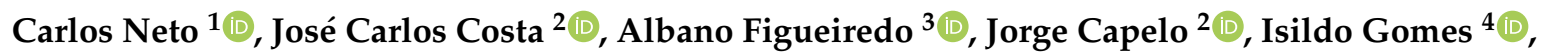 \\ Sónia Vitória ${ }^{5}{ }^{\mathbb{D}}$, José Maria Semedo ${ }^{5}$, António Lopes ${ }^{1}{ }^{\mathbb{D}}$, Herculano Dinis ${ }^{6}{ }^{\mathbb{D}}$, \\ Ezequiel Correia ${ }^{1}\left(\mathbb{D}\right.$, Maria Cristina Duarte ${ }^{7}\left(\mathbb{D}\right.$ and Maria M. Romeiras ${ }^{2,7, *(\mathbb{C})}$ \\ 1 Centre for Geographical Studies, Institute of Geography and Spatial Planning (IGOT), Universidade de \\ Lisboa, Rua Branca Edmée Marques, 1600-276 Lisboa, Portugal; cneto@campus.ul.pt (C.N.); \\ antonio.lopes@campus.ul.pt (A.L.); ezequielc@campus.ul.pt (E.C.) \\ 2 Linking Landscape, Environment, Agriculture and Food (LEAF), Instituto Superior de Agronomia (ISA), \\ Universidade de Lisboa, 1349-017 Lisboa, Portugal; jccosta@isa.ulisboa.pt (J.C.C.); jorge.capelo@iniav.pt (J.C.) \\ 3 Centre of Studies in Geography and Spatial Planning (CEGOT), Department Geography and Tourism, \\ University of Coimbra, Colégio de São Jerónimo, 3004-530 Coimbra, Portugal; geofig@fl.uc.pt \\ 4 Instituto Nacional de Investigação e Desenvolvimento Agrário (INIDA), Santiago, São Lourenço dos Orgãos \\ CP 84, Cape Verde; isildo.gomes@inida.gov.cv \\ 5 Campus do Palmarejo, Faculdade de Ciências e Tecnologia, Universidade de Cabo Verde, CP 279, Praia, \\ Santiago CP 279, Cape Verde; sonia.silva@docente.unicv.edu.cv (S.V.); jmsemedo@cvtelecom.cv (J.M.S.) \\ 6 Direção Nacional do Ambiente (DNA-CV) \& Associação Projecto Vitó, CP 47, Xaguate, S. Filipe, Ilha do Fogo \\ CP47, Cape Verde; pnfogo.segecol@gmail.com \\ 7 Centre for Ecology, Evolution and Environmental Changes (cE3c), Faculdade de Ciências, Universidade de \\ Lisboa, 1749-017 Lisboa, Portugal; mcduarte@fc.ul.pt \\ * Correspondence: mmromeiras@isa.ulisboa.pt
}

Received: 19 January 2020; Accepted: 15 February 2020; Published: 19 February 2020

check for updates

\begin{abstract}
The flora and vegetation of the archipelago of Cabo Verde is dominated by Macaronesian, Mediterranean, and particularly by African tropical elements, resulting from its southernmost location, when compared to the other islands of the Macaronesia (i.e., Azores, Madeira, Selvagens, and Canary Islands). Very likely, such a geographical position entailed higher susceptibility to extreme climatic fluctuations, namely those associated with the West African Monsoon oscillations. These fluctuations led to a continuous aridification, which is a clear trend shown by most recent studies based on continental shelf cores. Promoting important environmental shifts, such climatic fluctuations are accepted as determinant to explain the current spatial distribution patterns of taxa, as well as the composition of the plant communities. In this paper, we present a comprehensive characterization of the main plant communities in Cabo Verde, and we discuss the role of the climatic and topoclimatic diversity in shaping the vegetation composition and distribution of this archipelago. Our study reveals a strong variation in the diversity of plant communities across elevation gradients and distinct patterns of richness among plant communities. Moreover, we present an overview of the biogeographical relationships of the Cabo Verde flora and vegetation with the other Macaronesian Islands and northwestern Africa. We discuss how the distribution of plant communities and genetic patterns found among most of the endemic lineages can be related to Africa's ongoing aridification, exploring the impacts of a process that marks northern Africa from the Late Miocene until the present.
\end{abstract}

Keywords: vegetation; aridification in NW Africa; Macaronesian islands; distribution patterns; West African Monsoon (WAM); vascular flora 


\section{Introduction}

The study of deep-sea cores from the West African coast conducted in recent decades, in parallel with studies of the paleolakes that characterized the wet periods of the present Sahara desert (green Sahara Periods, or GSPs), and sedimentary structures associated with ancient rivers brought a new understanding of the history of West and North African vegetation [1-4]. Results from pollen sequences, which were used as proxies for flora and vegetation spatial patterns, were combined with data concerning dust carried from the Sahara desert, supporting the inference of paleoclimatic conditions, namely the influence of atmospheric circulation systems such as the West African Monsoon (WAM) and trade winds [5], and with changes in hydrology of the Sahara desert [6]. Such results are of critical importance to set the origin of Cabo Verde's flora and vegetation and clarify their relationships with the remaining flora and vegetation of northwestern Africa and the Mediterranean Basin.

The Atlantic archipelagos originated from mid-Tertiary volcanic cycles, spreading from $40^{\circ}$ to $15^{\circ} \mathrm{N}$ along the coasts of Europe and Africa, are known as Macaronesia, or "the Fortunate Islands": Azores, Madeira, Selvagens Islands, Canary Islands, and Cabo Verde (Figure 1). The almost linear geographical disposition of the archipelagos, and their approximately parallel position in relation to the African and European mainland, creating a chain of islands, are paramount to hypotheses explaining "Macaronesian" flora and vegetation features, namely colonization, dispersion, and speciation events [7].

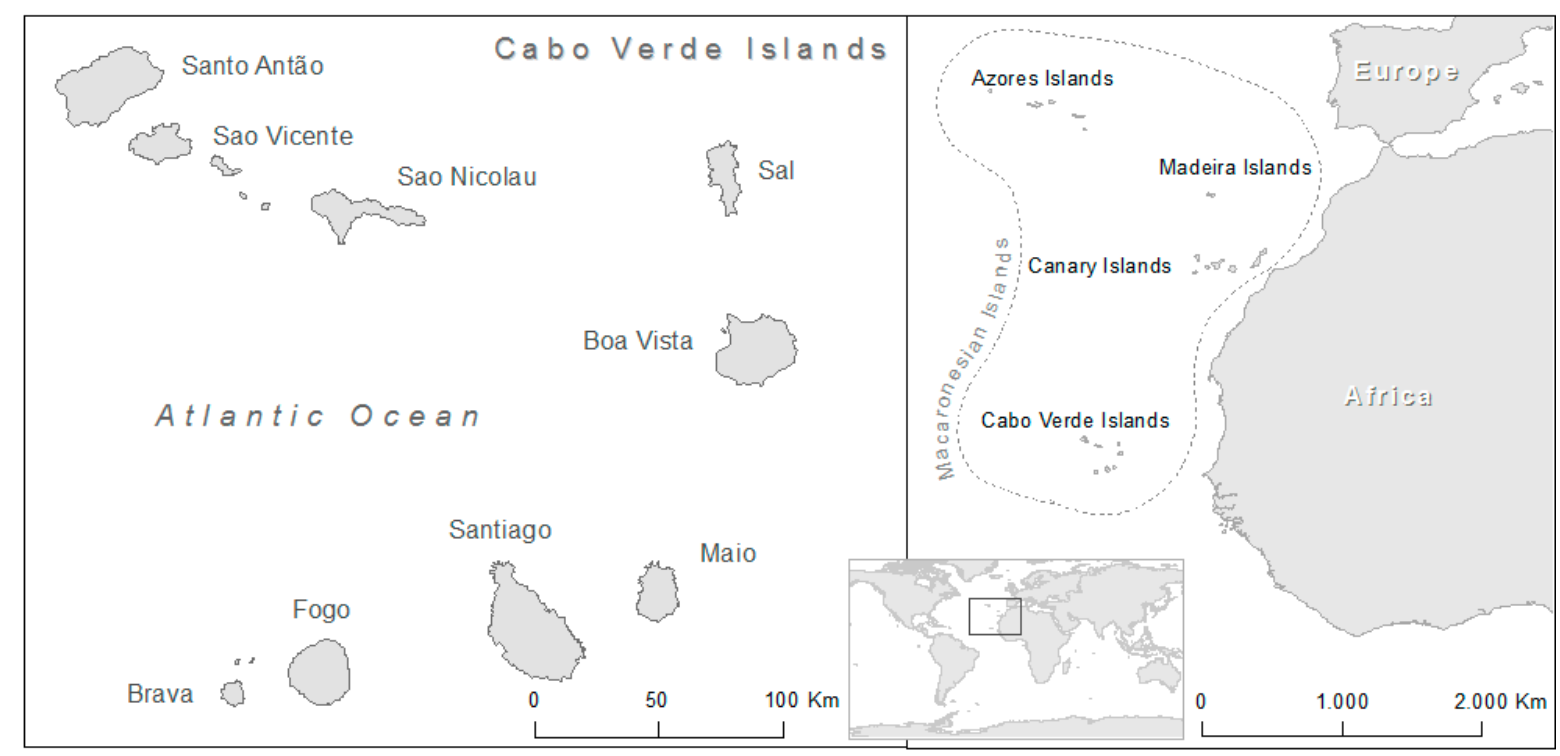

Figure 1. Cabo Verde location, with details of the Macaronesian Region.

In the continental areas surrounding Tethys, several violent disruptive environmental events took place during the mid and late Tertiary. The orogenic events associated with the alpine tectonic cycle and the onset of a summer-dry Mediterranean climate led to dramatic changes, extinctions, and novel evolutionary pressures on plant species and vegetation of those areas [8]. In this context, a global opportunity for the establishment of new migrant floras appeared, either from central Eurasia (neomediterranean) or high northern latitudes (Artho-Tertiary deciduous flora) [8]. Oceanic islands were not significantly affected by such complex phenomena during the Tertiary period, thus retaining part of the paleo-subtropical vegetation in relatively high latitudes. However, spatial changes of distribution took place, very likely contributing to the definition of low-saturated habitats, which is a feature also triggered by volcanic events, promoting windows for colonization $[9,10]$ by creating suitable conditions for new founders [11] that very often went through a process of speciation by adaptive radiation [12]. In fact, biogeographical relationships, mostly with the Mediterranean and African mainland areas, were conditioned by long-range dispersal events. 
Meanwhile, extensive speciation phenomena were taking place, which were rooted on both the ancestors from the Tertiary elements and the later newcomers from the continental areas [12]. Traditionally, the native vegetation and high prevalence of endemic elements in these islands were interpreted as relicts [13] of the subtropical Tertiary vegetation, the 'Geoflora vegetation', around the archaic Tethys basin (coarsely the Mediterranean Sea, spreading eastwards to include the present Black and Aral seas, reaching the Indian Ocean). This interpretation is challenged by increasing molecular and phylogeographical evidences $[14,15]$ supporting the derived neoendemic synapomorphic character. This is the case of woody endemics in taxonomical groups that normally present an herbaceous habit in continental areas, which is one of the most striking attributes in the floras of the Atlantic islands [14]. In fact, the woody habit is significant among the endemics, since several genera, subgenera, or sections underwent speciation in one or in several archipelagos, namely the Asteraceae (e.g., Asteriscus, Pericallis, Sonchus, Tolpis), Boraginaceae (Echium), Campanulaceae (Musschia in Madeira, Azorina in the Azores, Canarina in the Canary Islands, and Campanula in Cabo Verde), Scrophulariaceae (Isoplexis) and others such as Sideritis, Plantago, and Aeonium (respectively, Lamiaceae, Plantaginaceae, and Crassulaceae). These plants exhibit consistent habit and structure features, namely being rosulate, monocarpic, or candelabra-shaped, exhibiting the so-called "island-woodiness" effect [16]. Other important groups encompassing Cabo Verde vegetation are paleo-Mediterranean thermophilous sclerophylls, such as spurges Euphorbia (sect. Aphyllis) and Sideroxylon. The latter lineage has circum-Mediterranean-African-Arabic affinities (Rand Flora) and reached the islands in several cycles of colonization. Rand Flora are floristic elements of taxonomical non-sister clades that are consistently found with a correlated distribution area around the peripheral borders of the whole African continent, including areas surrounding the Mediterranean and Red Seas, with no obvious relationship with inland African continental flora [17]. Such context explains why Cabo Verde's flora combines significant Macaronesian radiations (e.g., Aeonium, Echium, Tolpis, and Sonchus) with continental African elements (e.g., Acacia, Dichrostachys, Ficus, Ziziphus, and Andopogoneae grasses). In short, Cabo Verde's flora can be coarsely grouped into five types: (1) Paleoendemic paleosubtropical forest flora of tethysian origin; (2) Neoendemic Macaronesian flora with island woodiness physiognomy; (3) Paleo-Mediterranean xeric to semi-desert, sclerophyllous, or succulent flora; (4) Continental African flora; and (5) Flora introduced since the human colonization of these islands, more than 500 years ago.

\section{Cabo Verde Islands: Origin and Climate}

The Cabo Verde archipelago is composed of 10 main islands and several islets (Figure 1). The islands account for $4033 \mathrm{~km}^{2}$ of total land area and are grouped into two main sets according to prevailing NE winds: The Windward islands—Santo Antão, São Vicente, Santa Luzia (the only uninhabited main island), São Nicolau, Sal, and Boavista—and Leeward islands: Maio, Santiago, Fogo, and Brava.

The genesis of the Cabo Verde archipelago is associated with intravolcanic plaque processes. According to some authors, who defend its origin from mantle plumes (hotspot) [18], there is a submerged crest connection between the Cabo Verde and Canary archipelagos, which also have a similar nature of volcanic episodes.

Hotspot activity started around 19 to $22 \mathrm{Ma}$, resulting in a large crustal uplift zone (Cabo Verde Swell) where the Cabo Verde islands are placed [19], and volcanic activity remains until present days. The topography is generally very rugged, associated with high massifs of volcanic origin, with well-preserved volcanic apparatuses, namely cones, craters, boilers (e.g., Chã das Caldeiras in Fogo and Cova in Santo Antão), and deep valleys. The island of Fogo reaches the highest elevation at $2829 \mathrm{~m}$, followed by Santo Antão, Santiago, and São Nicolau with 1979 m, 1392 m, and 1304 m, respectively [20].

Due to its northern position relative to the oscillation zone of the ITCZ (Intertropical Convergence Zone), Cabo Verde has a dry tropical climate with two well-marked seasons (humid and dry) conditioning the distribution of its flora and vegetation. However, the island topography contributes to significant spatial variations with altitude and exposure to prevailing winds, leading to contrasting 
weather conditions. South blowing wind during the few ITCZ passages north of the archipelago brings tropical humid air masses and heavy rainfall associated to the West African Monsoon (WAM); in contrast, northeast winds, mainly in the dry season, carry hot and dry air masses (Saharan): The Harmattan season [21].

For most of the year, and almost exclusively between December and June, Cabo Verde is under the influence of the eastern sector of the Azorean subtropical high-pressure cell, which is the origin of the boreal trade winds. The oceanic course of the air mass and the vertical structure is marked by a clear thermal inversion, whose base is on average between 380 and $850 \mathrm{~m}$, and the top at about $1400 \mathrm{~m}$ [22], favors the formation of stratiform cloud banks. The persistence of cloud banks, which is prompted by trade wind inversion on the north and northeast slopes on islands of wider altitudinal ranges, smoothens the characteristic dryness of the archipelago.

The orographic convection that occurs when the flow reaches the islands with the most vigorous reliefs reinforces the cloud thickness, which dissipates rapidly leeward due to the foehn effect, resulting in a clear dissymmetry between the northern and southern slopes. Windward areas experience a significant number of foggy days, not only at higher altitudes (e.g., Santiago Island, Serra da Malagueta, and Pico da Antónia: 1000-1300 m, about 200 days/year on average), but also in lower areas (e.g., S. Jorge dos Orgãos: $320 \mathrm{~m}$, about 180 days/year). On leeward areas, there are significantly fewer foggy days (e.g., Curralinho: 950 m, 100 days/year; Assomada plateau: 550 m, 15 days/year) [21].

The high frequency of clouds, besides reducing the amount of solar radiation reaching the surface, considerably increases the water availability in these areas through the interception of cloud droplets and the increase of condensation nuclei. Since the 1960s, various cloud water-harvesting experiments have been conducted on the highest sectors of Santo Antão, São Vicente, São Nicolau, Santiago, Fogo, and the Brava islands. The results show that the horizontal precipitation far outweighs vertical precipitation, more than doubling it in some cases [23], which is a volume similar to that recorded in other Macaronesian Islands [24,25]. Although the seasonal rhythm of horizontal precipitation is similar to that of vertical precipitation, with the highest values during the rainy season, its ecological significance is greater between November and March. During the dry season, as much as $100 \mathrm{~mm}$ were monthly recorded at Serra da Malagueta [26], between 40 and $100 \mathrm{~mm}$ at Pero Dias (Santo Antão) and 176 to $1029 \mathrm{~mm}$ at Campo das Fontes (Brava) [27].

According to the Worldwide Bioclimatic Classification system of Rivas-Martínez et al. [28], Cabo Verde's bioclimate ranges from tropical hyperdesertic to pluviseasonal, upper infra to low supratropical, and upper ultrahyperarid to upper dry, and it is occasionally subhumid (Supplementary Materials, Table S1).

\section{Plant Communities of Cabo Verde}

Spatial differences in the amount of precipitation, structured by topographic determinants (altitude and aspect), become evident when comparing the flatter eastern islands (i.e., Sal, Boavista, Maio), where the climate is arid, with the most mountainous islands (Santo Antão, São Nicolau, Fogo, Santiago, Brava), where a semiarid and dry bioclimatic pattern in the south-facing slopes, dominated by African floristic elements of savannoid or predesert character, are replaced by more humid conditions on the north/northeast-facing slopes, creating a significant climatic asymmetry $[28,29]$. To find a reasonably effective model to understand Cabo Verde's flora and vegetation chorology, we must add the influence of successive volcanic eruptions to the atmospheric circulation model and spatial distribution of topoclimates [30], as well as the particularly devastating anthropic impact of 500 years of human colonization [31-33]. The high level of landscape disturbance on the islands, which certainly led to the extinction of some plant species, such as Stachytarpheta fallax or Habenaria petromedusa, the two formally reported extinct species [34], hinders our capacity to provide a model for the pristine vegetation. Therefore, an approach must rely on data available for other Macaronesian archipelagos and consider models of distribution of African flora and vegetation that are closest to the ones of Cabo Verde, along with historical records from navigators and/or naturalists [33,35]. 
Based on the aforementioned contingencies, we discuss a distribution model of the vegetation of the Cabo Verde Islands, supported by published $[28,29,36]$ and unpublished work developed by the authors during the last decades. It must be noted that annual and ruderal communities were excluded from this study, as they are mainly dominated by exotic plants that have become naturalized in Cabo Verde. Some exotic plants are invading and dominating natural communities, thus constituting one of the most serious threats to plant communities, which are nowadays very strongly affected by human actions. According to the Cabo Verde Red List [34], most of the strong anthropic disturbances were recorded between 400 and $1200 \mathrm{~m}$ in mountainous islands (Santo Antão, São Nicolau, Fogo, Santiago, Brava), whereas tourism has threatened the lowland coastal plant communities, which occur in Eastern Islands of Sal and Boavista [34]. Moreover, natural disasters, specifically recent volcanic events (in 2014), have had an impact on plant communities that occur above $1600 \mathrm{~m}$ on Fogo Island.

In this section, we present a characterization of the main plant communities in Cabo Verde, which still constitute the dominant elements of the native vegetation of these islands [i.e., 3.1. Ficus and Sideroxylon woodlands (Figure 2A);3.2. Acacia savannas (Figure 2B);3.3. Other arborescent communities (Figure 2C,D); 3.4. Shrub vegetation (Figure 2E,F); 3.5. Grasslands (Figure 2G); 3.6. Halophytic and hydrophytic communities (Figure 2H); and 3.7. Chasmophytic communities (Figure 2I)]. Nomenclature follows Rivas-Martínez et al. [28] and POWO-The Plants of the World Online portal [37].

\subsection{Ficus and Sideroxylon Woodlands}

Speaking of forests in Cabo Verde today may seem somewhat speculative, as only a few native tree species occur, and especially in areas of higher humidity and/or less accessibility. The restriction of plant communities dominated by native trees is linked to the fact that in general, endemics are more vulnerable to the browsing of introduced herbivores (e.g., goats), as shown by Cubas et al. [38] for Tenerife. In addition, the harvesting of firewood for domestic use and human-induced fires are particularly destructive to the forest areas of island ecosystems [39].

In mountainous islands, the possible past occurrence of arboreal vegetation is based on the current existence of several native taxa that are capable of phanerophytic structure (e.g., Ficus sur and F. sycomorus (Figure 2A), Dichrostachys cinerea subsp. platycarpa, and Sideroxylon marginatum), which could form open forests or woodlands. The model considers suitable conditions for three types of woodlands, two of which are clearly dominated by tropical fig trees (F. sur and F. sycomorus) and one corresponding to open forests of Sideroxylon marginatum (Table S2), which are currently restricted to very small patches.

In areas with the highest vertical and horizontal precipitation values, the potential forests (woodlands) are dominated by F. sur at higher altitudes and by F. sycomorus at lower altitudes. In both cases, the phenological regime of these fig trees is similar to that of an evergreen forest, which is an outstanding feature when compared to the deciduous response pattern to the dry season found in continental Africa [40]. Outside the fog belt, sycamore fig trees (F. sycomorus) occur at valley bottoms, where floristic elements from arid and semi-arid environments are present, such as Cocculus pendulus and Ziziphus mauritiana, as well as tropophytic savannoid elements in an edaphic hygrophilic position according to a recurring tropical dry worldwide model [41], representing a process of isolation of high water-demanding flora and vegetation [29]. Currently, there are only a few specimens of isolated fig trees, which are rarely larger than $30 \mathrm{~cm}$ in diameter. These tropophytic and phreatophytic figs were first observed by Diogo Gomes (ca. 1420-1500), who was a Portuguese sailor that provided the earliest explicit reference to the large number of highly productive fruiting fig trees on the island of Santiago [33]. 

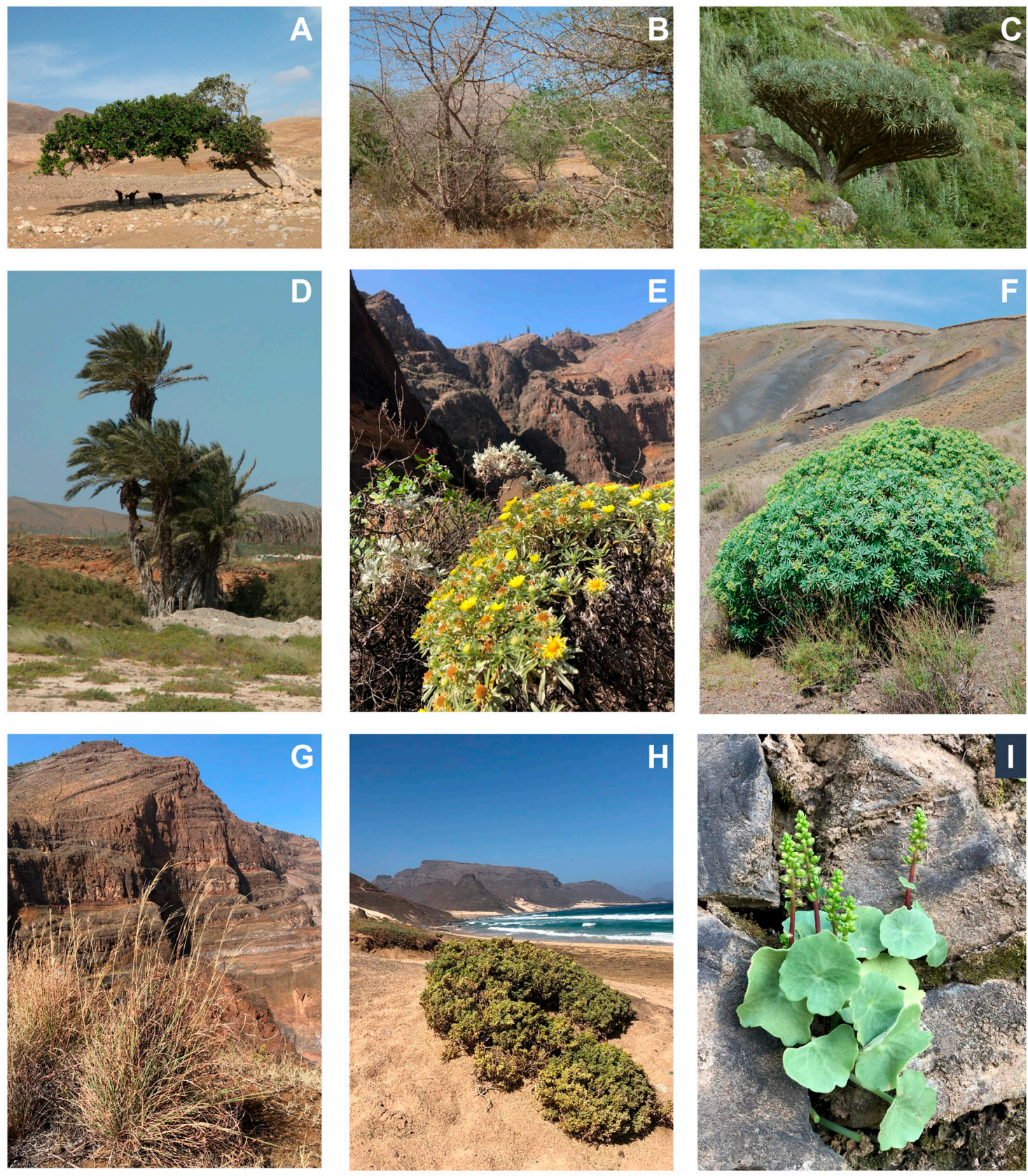

Figure 2. Representative species of some of the main plant communities in Cabo Verde. Woody elements present in woodlands and savannas at lowlands: Ficus sycomorus (A), Acacia caboverdeana (B), and in mountainous slopes, Dracaena caboverdeana (C). Riparian streams, near the coast: Phoenix atlantica (D). Shrub communities: Asteriscus vogelii and Artemisia gorgonum (E) and Euphorbia tuckeyana (F). Perennial grasslands at high altitudes: Hyparrhenia caboverdeana $(\mathbf{G})$. Coastal halophytic communities: Tetraena vicentina $\mathbf{( H )}$. Upland chasmophytic communities: Umbilicus schmidtii (I). Photos by M. Cristina Duarte (A-D) and Maria Romeiras (E-I).

Another evergreen woodland described for Cabo Verde [28] is dominated by the endemic marmulano of Cabo Verde (S. marginatum), which is a small tree that, similar to the fig trees, is found only in the cracks of rocky walls, rarely with significant trunk diameters. It is a paleosubtropical paleoendemic element, which occurs in the driest parts of the fog-influenced areas, with an identical position to that of the communities of S. mirmulans in Madeira or the Canarian microforest of $S$. canariense. It is an evergreen woodland that includes many deciduous nanophanerophytic elements, many of them Cabo Verde endemics [e.g., Aeonium gorgoneum, Echium stenosiphon, Euphorbia tuckeyana, 
Lavandula rotundifolia, Lotus jacobaeus, Launaea picridioides, and Lobularia fruticosa, among others]. Although present in almost all the islands, its abundance is higher in islands with a more significant fog belt (namely, Santo Antão, São Nicolau, Santiago, and Fogo), where it extends beyond this fog belt [28]. Such a distribution model for $S$. marginatum is not only congruent with the anthropic destruction of a large part of the population [38], but also with the ecological constraints that prevent it from colonizing drier habitats: this limitation does not apply to shrubs present in the community, since their larger ecological plasticity allows them to develop in more xeric habitats.

This model is consistent with the latest genetic analyses regarding the divergence between taxa usually associated with Rand Flora (Afro-Mediterranean phytogeographic pattern that evolutionarily relates floras of disjunct regions such as Macaronesia, Northwest and South Africa, and Southern Arabia, among others) [42-44]. Older divergences are identified in sub-humid affinity taxa [e.g., Sideroxylon-17.5 Ma (10-26.2 Ma)], and those with more affinities with arid territories diverge later [e.g., Campylanthus - 7.5 Ma (3.1-14.2 Ma)] [17]. The work of Pokorny et al. [17] demonstrates that the aridification of northwestern Africa, despite successive interruptions by GSPs, caused divergences in different periods of time for different taxa, depending on their ecological requirements, which is a process that still marks current spatial distribution patterns.

\subsection{Acacia Savannas}

Under arid, semi-arid, and dry conditions, vegetation becomes dominated by tropical Acacia savannas (Acacia caboverdeana, Figure 2B), which are an African element in the vegetation of Cabo Verde that potentially covers most of the islands. This species, recently described as new to this archipelago by Rivas-Martínez et al. [28], was previously identified as Faidherbia albida. This species occurs in much of Africa in forest galleries along rivers and is a frequent floristic element in open deciduous rainforests and, mainly, savannas [45], requiring a long dry season and permanent access to ground water. Under natural conditions, F. albida is found close to temporary rivers and in gullies and ravines [46] or rocky areas, similar to A. caboverdeana in Cabo Verde, extending its roots to a depth of 8 $\mathrm{m}$ [47]. Faidherbia albida has been greatly spread by man due to its utility for livestock feeding and for undercover agriculture because of its deciduousness in the wet season [47,48]. In Cabo Verde, the potential area of A. caboverdeana is occupied by plantations of Prosopis juliflora, and only sporadically, as in Ribeira da Barca (Santiago), is it possible to find a small sample of what the pristine savannas of Acacia in Cabo Verde might have been. Chevalier [49] presents some photos of A. caboverdeana near the city of Praia (on sandy soil near the sea) with logs larger than $30 \mathrm{~cm}$.

These tropophytic Afrotropical savannas of A. caboverdeana (Table S2) are present in all islands, and they are accompanied by other micro and mesophanerophytic elements, such as Dichrostachys cinerea subsp. platycarpa and Ziziphus mauritiana and, less frequently, in plant communities dominated by endemic shrubs. In the understory, savannas frequently present a graminoid matrix of tropical continental African flora.

\subsection{Other Arborescent Communities}

Formerly relevant in structuring the woody communities in the Cabo Verde archipelago are the endemic elements Dracaena caboverdeana (Figure 2C) and Phoenix atlantica (Figure 2D), and the native non-endemic Tamarix senegalensis.

The symbolic dragon tree Dracaena caboverdeana only occurs in small patches in Santo Antão and São Nicolau [34]. Palm groves of the remarkable endangered Phoenix atlantica can still be seen in the eastern and southern islands of Cabo Verde, growing on riparian streams, mostly near the coast, with temporary hydromorphy. Cocculus pendulus and Ziziphus mauritiana are some of the few species present in these restricted communities.

Present in most islands of the archipelago, galleries of tamarisk grow by temporary watercourses and torrents with generally scarce intermittent flow. These communities are similar to the riparian thicket savannas with Tamarix spp. of West Africa (Sahara, Mauritania, and Senegal) [50]. 


\subsection{Shrub Vegetation}

The shrub formations of Cabo Verde (Figure 2E,F) are mainly found in zones of medium to high elevations above $400 \mathrm{~m}$, and the levels of endemism increase with elevation, as proposed by Steinbauer et al. [51]. The shrub vegetation is dominated by endemic species, showing a comparable pattern to Canary Islands $[52,53]$ with a clear spatial pattern, with hotspots of endemic rarity found at high elevations and in specific habitats, namely in northeast-facing cliffs, of the Natural Parks of Moroços, Cova, and Ribeira da Torre (Santo Antão); Monte Gordo (São Nicolau); Serra da Malagueta (Santiago); Monte Verde (São Vicente); and Chã das Caldeiras (Fogo Island) [54].

Among the shrub vegetation, the endemic Euphorbia tuckeyana (Figure 2F) define a wide diversity of plant communities (Table S2) depending on each island's endemic species and/or taxa of restricted distribution and on certain specific ecological characteristics. These communities are rich in endemic species, most of them with either a shrubby or a subshrubby habit (e.g., Aeonium gorgoneum, Artemisia gorgonum, Campylanthus glaber, Conyza feae, Echium hypertropicum, E. vulcanorum, Euphorbia tuckeyana, Globularia amygdalifolia, Lavandula rotundifolia, and Periploca chevalieri).

As stated above, most of these communities occur on NE slopes above $400 \mathrm{~m}$, where higher values of precipitation occur. The presence of endemic shrub formations at lower altitudes and drier areas is associated with situations of edaphic compensation, namely block accumulation at the base of basaltic rock walls. A similar model was proposed by Esler et al. [41] for the deserts of southern Africa, where shrub and succulent vegetation becomes dominant on stony soils that receive less than $200 \mathrm{~mm}$ of rainfall/year.

\subsection{Grasslands}

In xeric environments, woody elements are rare, and communities are dominated by perennial or short-lived herbaceous grasses such as Bothriochloa bladhii, Enneapogon desvauxii, and Tetrapogon cenchriformis. In mountainous islands, these communities are enriched by Andropogon gayanus, Chloris pycnothrix, Heteropogon melanocarpus, Hyparrhenia caboverdeana (Figure 2G), Setaria parviflora, and Rottboellia cochinchinensis, among others. As a whole, such herbaceous communities are physiognomically and structurally close to the dry tropical West African graminoid vegetation, sharing numerous taxa with it [28].

After rainy periods, ephemeral grasslands composed of annual grasses, such as the endemics Aristida cardosoi and Brachiaria lata subsp. caboverdeana, and broad-leaved herbs, such as Cleome viscosa, C. brachycarpa and Heliotropium crispum, flourish in the lowlands of all the islands.

\subsection{Halophytic and Hydrophytic Communities}

Halophytic communities are common in Cabo Verde, but they are particularly important in the Eastern islands of Sal, Boavista, and Maio, as well as in S. Vicente. In coastal sand dunes, the xerophilous communities are dominated by perennial rhizomatous species such as the graminoids Sporobolus spicatus and Cyperus crassipes, two widespread African species, or by the dwarf shrubs Lotus brunneri, Polycarpaea caboverdeana, Pulicaria diffusa, and Tetraena vicentina (Figure 2H).

The particular topographic and hydrographic features of the eastern islands favor the occurrence of saltwater marshes. These permanent succulent halophilous communities grow on coastal sandy soils, are temporarily or occasionally flooded by sea tides, and are dominated by the succulent shrub Arthrocaulon franzii and the small forb Cressa salina. Similar communities are present in the western coasts of the African continent, mainly from Morocco to Senegal [51]. Intermingled with these woody marshes, small herbaceous communities of succulents occur, including Sesuvium portulacastrum subsp. persoonii, S. sesuvioides, and Blutaparon vermiculare. 


\subsection{Chasmophytic Communities}

Humid and shady basaltic walls, permanently or temporarily water-flushed, support perennial communities of chasmophytic species such as the tropical ferns Adiantum capillus-veneris subsp. trifidum, Hypodematium crenatum, and Pteris vittata.

In mountainous islands, perennial rupicolous communities grow on basaltic, mafic ultramafic rocky walls and cliffs that are wetted only during the rainy season. Characteristic species vary with the island and comprise the pteridophytes Hemionitis acrostica and Cosentinia vellea and shrub or subshrub chasmophytes, including a wide diversity of endemic taxa belonging to genera such as Campylanthus, Kickxia, Launaea, Sonchus, and Umbilicus (Figure 2I). Ferns such as Adiantum incisum and A. philippense, as well as some cosmopolite rupicolous species are present in nitrogen-rich habitats in urban or rural areas. These communities develop under less humid conditions than those previously listed.

\section{Aridification of Northern Africa and Its Role in Shaping the Vegetation of Cabo Verde}

Explanation of the current features of the archipelago's flora and vegetation requires arguments concerning the climatic changes that have occurred in Africa since the Miocene. The early Miocene (23-16 Ma) was globally hot and humid, with rainforests extending from northern Africa to nearly southern Africa [17]. The Middle Miocene (16-11.6 Ma) marks the beginning of the change toward aridity, although this aridification began in the SW (Namib Desert, Congo Basin) 17-16 Ma earlier (lower Mid-Miocene), and in North Africa, the first evidence of Saharan aridification only appears in the Late Miocene (11.6-5.3 Ma) [55]. However, this aridification trend is marked across North and Northwest Africa by strong aridity waves interrupted by humidity episodes known as GSPs (green Sahara Periods) [56,57]. More than 230 GSPs since 8 Ma have been documented [58], and their importance for vegetation distribution models in North and Northwest Africa cannot be discarded [2,17,56,58-62]. The alternate episodes of humidity and aridity of the aridification trend of northern Africa since the Miocene are the keystone of the irradiation phenomena of North African flora that, depending on their ecological valence, diverged into isolated and genetically differentiated populations following a similar model, but these are temporally different due to their ecology (the most humidity demanding elements present older divergences) $[17,63,64]$. In the Quaternary, two of these GSPs, respectively Eemian (130-115 Ky corresponding to Marine Isotope Stage 5e) and the early Holocene (11-5 ka), are relatively well documented $[2,54,55,59,65,66]$ and are of great importance for the evolution of northern and northwestern African vegetation (including the Cabo Verde archipelago). During GSPs, WAM penetrates further north, and higher precipitation than today generated a series of inland Sahara lakes and permanent rivers [3,4]. During the Holocene GSP, the vegetation is characterized by an advance of wooded savannas northwards, occupying what is now the arid and hyperarid Sahara Desert [17]. The currently accepted general model refers to a progressive development of forests and wooded savannas during interglacial periods as a result of the intensification and latitude rise of WAM (with increased precipitation) and a decrease in vegetation cover during glaciations with a greater influence of continental trade winds. In the continental shelf cores, dusts of terrestrial origin present a minimum concentration during the interglacial periods (higher vegetation cover) and the opposite during the glacial periods. In Cabo Verde Islands, such an oscillation is recorded in the alternation of calcrete (hot and arid conditions), sand dunes (dry and cold conditions), and paleosols (wetter periods) [67,68].

In general, the endemic shrub species have a strong ecological resilience, resulting from the filtering effect of recurrent dry periods that mark the ongoing African aridification since the terminal Miocene [63]. This aridification must have led to mass extinction phenomena, and only taxa of greater plasticity managed to survive. We can assume that episodes of dryness played a more important role in Cabo Verde than in the other islands of Macaronesia. Such an assumption is based on the fact that arid and semi-arid conditions have been expanding in altitude in southernmost Macaronesian archipelagos, in a model that inevitably leads to the restriction/disappearance of the higher humid and colder zones. Such an idea is also supported by analyses of deep-sea cores from the African west coast, some of which fall between Cabo Verde and the Canary Islands. Analyses of pollen $[69,70]$ and of Saharan 
dust (among others) from marine sedimentary series show that the recurrent periods of intensification of WAM affected the Cabo Verde archipelago much more than the rest of Macaronesia due to its geographical position. Such oscillations between arid/cooler and warmer/wet phases are also recorded in sedimentary sequences in all Macaronesian islands, and Cabo Verde is no exception, despite its southernmost position (see Figueiredo [71]). The recurrence of severe aridity periods, interspersed with periods of WAM intensification, led to several repetitions of the contraction and expansion phenomenon. For instance, the genetic patterns of E. tuckeyana, the main constituent of Cabo Verde's shrub formations, occur from sea level to near $2000 \mathrm{~m}$ in Fogo Island, with great ecological plasticity. In a recent work about the phylogeography of sect. Aphyllis subsect. Macaronesicae (Euphorbiaceae), Barres et al. [72] suggest that the ancestor of subsect. Macaronesicae was adapted to arid or mesic habitats, and the traits associated with humid habitats were acquired later. Tenerife island (Canary Islands) is considered the origin of the group, and two colonization events are identified, one of them originating E. tuckeyana in Cabo Verde, which shows an ancient separation from the ancestor of the rest of the species present in the other Macaronesian archipelagos. The low genetic differentiation found within Cabo Verde populations suggests a recent colonization, although the coincident arrival of the taxon with the beginning of the aridification of north and northwest Africa and climate change very likely promoted divergence between E. tuckeyana of Cabo Verde and the rest of sect. Aphyllis (5.5 Ma) [17]. Barres et al. [72] document differentiation between the populations of the northern and southern Cabo Verde Islands, which is also reported for other lineages, such as Globularia amygdalifolia and Umbilicus schmidtii [54], Echium [73], and Campanula jacobaea [74]. Menezes et al. [75] estimate 9.56 Ma as the age of divergence between Cabo Verde's endemic Campanula species (C. jacobaea and C. bravensis) and their African sister species, i.e., it is related to the beginning of the aridification process of North and Northwest Africa. However, the divergence between C. jacobaea and C. bravensis is recent (Pleistocene, 0.01 Ma) [75].

The genetic patterns found in Cabo Verde for the mentioned lineages were probably shaped by a combination of climate-driven expansion/contraction, recolonization, and extinction, following the tertiary and quaternary climate fluctuations discussed above. These climatic oscillations can be the true sculptors of the distribution model of flora and vegetation in Cabo Verde, as they are in continental Africa [76]. In fact, the successive periods of contraction and expansion controlled by WAM fluctuations mark the genetic patterns and the current distribution of plant species and, therefore, of communities in Cabo Verde archipelago. We can speculate that some Macaronesian taxa reached the archipelago (for example E. tuckeyana) in the late Miocene, during wetter periods than the current one, followed by periods of great aridity, which are responsible for the significant contraction of the established populations. Most taxa that form the dominant shrub communities in Cabo Verde apparently have high resilience and great ecological valence (especially in relation to dryness), which is certainly related with the original lapilli system that allowed subsurface water retention or even the frequent block accumulation at the base of the numerous basaltic rock walls. The expansion of these shrub communities during favorable climatic phases must have been rapid, with available habitats and little competition, especially if occurring after volcanic events.

Moreover, the rise and fall of the sea levels also plays an important role when studying the evolutionary processes in Cabo Verde due to their influence on the available terrestrial area of the islands [77]. For instance, during the glacial periods, the terrestrial area increased, promoting high gene flow among populations across the islands, followed by isolation after the retraction of populations to the middle-upper areas of the mountains during the interglacial periods (reviewed by Romeiras et al. [78]).

Although the above-mentioned hypotheses can contribute to explain some of the patterns of diversity found in these islands, the distribution of plant communities is currently strongly conditioned by human actions, namely habitat destruction and the introduction of non-native taxa [34]. These anthropogenic pressures interact with climate change impacts and will increase threats to insular floras during the 21st century $[79,80]$. Over the past decades, Cabo Verde has been affected by serious and 
prolonged droughts [81] that have negative impacts on the distribution and abundance of the endemic plant species, which have already small population sizes and occur in fragmented habitats [34].

\section{The Lack of Cloud Forests Dominated by Lauroid Taxa}

A remarkable feature of the Cabo Verde shrublands is clearly associated to their composition: under similar bioclimatic conditions as in Madeira and in the Canary Islands, namely in areas of high prevalence of cloud-banks, it is possible to find some species belonging to major Macaronesian radiations (e.g., Aeonium, Campylanthus, Echium, Limonium, Sonchus, Tolpis) $[10,54,78,82]$. However, data supporting the possibility that Lauraceae reached the Cabo Verde archipelago are lacking [7,83]. A recent paleoecological study by Castilla-Beltrán et al. [84] on the vegetation of São Nicolau's highlands has shed light on these questions, showing a pre-human landscape (5900-410 cal yr BP) characterized by shrubs and trees including Euphorbia tuckeyana, Ficus, Dracaena, and Tamarix.

There is no evidence that the laurel forest found in Azores, Madeira, and the Canary Islands survived in Cabo Verde, contributing to increase the debate about the definition of the Macaronesian Region as a biogeographic unit. For instance, the endemic shrub vegetation, which is mainly found in mountain areas (see Section 3.4), is closely related to other lineages from the Canary and Madeira archipelagos. On the other hand, the native grass species occurring in the arid lowlands of the archipelago (see Section 3.5 grassland communities) share more affinities with Tropical Africa. Therefore, the position of Cabo Verde is currently interpreted from a new perspective, following recent advances with other taxonomic studies (for more details, see Freitas et al. [85]).

\section{Conclusions}

The most recent studies on the vegetation of Cabo Verde highlight the coexistence between Macaronesian and Mediterranean floristic elements, and African tropical continental flora. The evolutionary history of Cabo Verde's endemic lineages is still understudied, particularly when compared to the other Macaronesian archipelagos [78]. Recent studies of some Cabo Verde's plant lineages, coupling morphological and genetic analyses, revealed unexpectedly high diversity and putative undescribed species [54]. Nevertheless, divergences within the archipelago are recent (for more details, see Romeiras et al. [78]), leading us to conclude that they possibly are recent expansions. This could be associated with climatic fluctuations that affect all northern Africa since the late Miocene until present, causing repeated phenomena of expansion and contraction of taxa distribution and, very likely, extinction, associated with the West African Monsoon oscillations. Such oscillations led to more significant impacts in Cabo Verde archipelago than in the other Macaronesian Islands because of its geographical position. Thus, interpretation of current distribution patterns of Cabo Verde's vegetation, as well as of genetic patterns, is linked with increasing dryness (climate-driven extinction) intercalated with more humid periods, favoring rapid expansion phenomena. Such successions of wet and dry periods shaped the particular features of the flora and vegetation of Cabo Verde relative to the remaining Macaronesian archipelagos, namely the more considerable presence of African elements, which is clearly observed in the fog belt colonized by African continental forest species of possibly recent colonization rather than by Lauraceae.

Supplementary Materials: The following are available online at http://www.mdpi.com/1424-2818/12/2/80/s1, Table S1: Bioclimates, thermotypes, and ombrotypes present in Cabo Verde (adapted from Rivas-Martínez et al. [28]), Table S2: Plant communities present in Cabo Verde (excluding ruderal communities), bioclimatic characterization and respective syntaxonomic framework [Class (Cl.), Order (Or.), Alliance (Al.), Association (As.)] (adapted from Rivas-Martínez et al. [28]).

Author Contributions: Conceptualization, C.N.; draft preparation, C.N., M.M.R.; investigation, C.N., J.C.C., M.C.D., and M.M.R..; writing-review and editing, C.N, M.C.D., and M.M.R. Revised the final version of this manuscript C.N, J.C.C., A.F., J.C., I.G., S.V., J.M.S., A.L.; H.D.; E.C., M.C.D., and M.M.R. All authors have read and agreed to the published version of the manuscript. 
Funding: This research was funded by Fundação para a Ciência e Tecnologia (FCT) and Aga Khan Development Network (AKDN) under the project CVAgrobiodiversity/333111699. Also to research units: UID/AGR/04129/2020 (LEAF) and UID/BIA/00329/2020 (cE3c), funded by Portuguese National Funds through FCT, Portugal.

Acknowledgments: The authors would like to acknowledge the supported provided by Fundação para a Ciência e Tecnologia (FCT) and Aga Khan Development Network (AKDN).

Conflicts of Interest: The authors declare no conflict of interest. The funders had no role in the design of the study; in the collection, analyses, or interpretation of data; in the writing of the manuscript, or in the decision to publish the results.

\section{References}

1. Armitage, S.J.; Bristow, C.S.; Drake, N.A. West African monsoon dynamics inferred from abrupt fluctuations of Lake Mega-Chad. Proc. Natl. Acad. Sci. USA 2015, 112, 8543-8548. [CrossRef] [PubMed]

2. Grant, K.M.; Rohling, E.J.; Westerhold, T.; Zabel, M.; Heslop, D.; Konijnendijk, T.; Lourens, L. A 3 million year index for North African humidity/aridity and the implication of potential pan-African Humid periods. Quat. Sci. Rev. 2017, 171, 100-118. [CrossRef]

3. Skonieczny, C.; Paillou, P.; Bory, A.; Bayon, G.; Biscara, L.; Crosta, X.; Eynaud, F.; Malaizé, B.; Revel, M.; Aleman, N.; et al. African humid periods triggered the reactivation of a large river system in Western Sahara. Nat. Commun. 2015, 6, 6-11. [CrossRef] [PubMed]

4. Wu, J.; Liu, Z.; Stuut, J.B.W.; Zhao, Y.; Schirone, A.; de Lange, G.J. North-African paleodrainage discharges to the central Mediterranean during the last 18,000 years: A multiproxy characterization. Quat. Sci. Rev. 2017, 163, 95-113. [CrossRef]

5. Rognon, P.; Coudé-Gaussen, G. Paleoclimates Off Northwest Africa $\left(28^{\circ}-35^{\circ} \mathrm{N}\right)$ about 18,000 yr B.P. Based on Continental Eolian Deposits. Quat. Res. 1996, 46, 118-126. [CrossRef]

6. Kröpelin, S.; Verschuren, D.; Lézine, A.-M.; Eggermont, H.; Cocquyt, C.; Francus, P.; Cazet, J.-P.; Fagot, M.; Rumes, B.; Russell, J.M.; et al. Climate-Driven Ecosystem Succession in the Sahara: The Past 6000 Years. Science 2008, 320, 765-768. [CrossRef]

7. Fernández-Palacios, J.M.; De Nascimento, L.; Otto, R.; Delgado, J.D.; García-Del-Rey, E.; Arévalo, J.R.; Whittaker, R.J. A reconstruction of Palaeo-Macaronesia, with particular reference to the long-term biogeography of the Atlantic island laurel forests. J. Biogeogr. 2011, 38, 226-246. [CrossRef]

8. Carrión, J.S.; Fernández, S.; Jiménez-Moreno, G.; Fauquette, S.; Gil-Romera, G.; González-Sampériz, P.; Finlayson, C. The historical origins of aridity and vegetation degradation in southeastern Spain. J. Arid. Environ. 2010, 74, 731-736. [CrossRef]

9. Patino, J.; Whittaker, R.J.; Borges, P.A.; Fernández-Palacios, J.M.; Ah-Peng, C.; Araújo, M.B.; Ávila, S.P.; Cardoso, P.; Cornuault, J.; de Boer, E.J.; et al. A roadmap for island biology: 50 fundamental questions after 50 years of The Theory of Island Biogeography. J. Biogeogr. 2017, 44, 963-983. [CrossRef]

10. Carine, M.A. Spatio-Temporal Relationships of the Macaronesian Endemic Flora: A Relictual Series or Window of Opportunity? Taxon 2005, 54, 895-903. [CrossRef]

11. Whittaker, R.J.; Triantis, K.A.; Ladle, R.J. A general dynamic theory of oceanic island biogeography. J. Biogeogr. 2008, 35, 977-994. [CrossRef]

12. Kim, S.-C.; McGowen, M.R.; Lubinsky, P.; Barber, J.C.; Mort, M.E.; Santos-Guerra, A. Timing and Tempo of Early and Successive Adaptive Radiations in Macaronesia. PLoS ONE 2008, 3, e2139. [CrossRef]

13. Bramwell, D. Endemism in the flora of the Canary Islands. In Taxonomy, Phytogeography and Evolution; Valentine, D.H., Ed.; Academic Press: Cambridge, MA, USA, 1972.

14. Böhle, U.-R.; Hilger, H.H.; Martin, W.F. Island colonization and evolution of the insular woody habit in Echium, L. (Boraginaceae). Proc. Natl. Acad. Sci. USA 1996, 93, 11740-11745. [CrossRef] [PubMed]

15. Kim, S.-C.; Crawford, D.J.; Francisco-Ortega, J.; Santos-Guerra, A. A common origin for woody Sonchus and five related genera in the Macaronesian Islands: Molecular evidence for extensive radiation. Proc. Natl. Acad. Sci. USA 1996, 93, 7743-7748. [CrossRef]

16. Lens, F.; Davin, N.; Smets, E.; del Arco, M. Insular woodiness on the Canary Islands: A remarkable case of convergent evolution. Int. J. Plant. Sci. 2013, 174, 992-1013. [CrossRef]

17. Pokorny, L.; Riina, R.; Mairal, M.; Meseguer, A.S.; Culshaw, V.; Cendoya, J.; Sanmartín, I. Living on the edge: Timing of Rand Flora disjunctions congruent with ongoing aridification in Africa. Front. Genet. 2015, 6, 1-15. [CrossRef] 
18. Holmes, J.A. How the Sahara became dry. Science 2008, 320, 752-753. [CrossRef]

19. Plesner, S.; Holm, P.M.; Wilson, J.R. 40-39 Ar geochronology of Santo Antão, Cape Verde Islands. J. Volcanol. Geoth. Res. 2003, 120, 103-121. [CrossRef]

20. Victória, S. Caracterização geológica e geotécnica das unidades litológicas da Cidade da Praia, ilha de Santiago, Cabo Verde. Ph.D. Thesis, University of Coimbra, Coimbra, Portugal, 2013. Available online: http://www.portaldoconhecimento.gov.cv/handle/10961/2471 (accessed on 17 February 2020).

21. Correia, E. Contribuições para o conhecimento do clima de Cabo Verde. Garcia de Orta Sér. Geogr. 1996, 15, 81-107.

22. Soares, E. Variabilidade climática na região de Cabo Verde. Master's Thesis, University of Évora, Évora, Portugal, 2004. Available online: http://www.icterra.pt/ (accessed on 17 February 2020).

23. Furtado, F.J.R. A Captação de Água no Nevoeiro no Parque Natural de Serra Malagueta. Master's Thesis, University of Aveiro, Aveiro, Portugal, 2009. Available online: http://hdl.handle.net/10773/629 (accessed on 17 February 2020).

24. Ritter, A.; Regalado, C.M.; Aschan, G. Fog reduces transpiration in tree species of the Canarian relict heath-laurel cloud forest (Garajonay National Park, Spain). Tree Physiol. 2009, 29, 517-528. [CrossRef]

25. Prada, S.; de Sequeira, M.M.; Figueira, C.; Vasconcelos, R. Cloud water interception in the high altitude tree heath forest (Erica arborea L.) of Paul da Serra Massif (Madeira, Portugal). Hydrol. Process. 2012, 26, $202-212$. [CrossRef]

26. Acosta Baladón, A.; Gioda, A. L'importance des précipitations occultes sous les tropiques secs. Sécheresse 1991, 2, 132-134.

27. Cunha, F.R. Problema da Captação da Água de Nevoeiro em Cabo Verde. Garcia de Orta 1964, 12, 719-754.

28. Rivas-Martínez, S.; Lousã, M.; Costa, J.C.; Duarte, M.C. Geobotanical survey of Cabo Verde Islands (West Africa). Int. J. Geobot. Res. 2017, 7, 1-103.

29. Duarte, M.C.; Rego, F.; Moreira, I. Distribution patterns of plant communities on Santiago Island, Cape Verde. J. Veg. Sci. 2005, 16, 283-292. [CrossRef]

30. Díaz-Pérez, A.; Sequeira, M.; Santos-Guerra, A.; Catalán, P. Multiple colonizations, in situ speciation, and volcanism-associated stepping-stone dispersals shaped the phylogeography of the Macaronesian red fescues (Festuca, L., Gramineae). Syst. Biol. 2008, 57, 732-749. [CrossRef]

31. Duarte, M.C.; Moreira, I. A vegetação de Santiago (Cabo Verde). Apontamento histórico. Garcia de Orta Sér. Bot. 2002, 16, 51-80.

32. Caujapé-Castells, J.; Tye, A.; Crawford, D.J.; Santos-Guerra, A.; Sakai, A.; Beaver, K.; Lobin, W.; Vincent Florens, F.B.; Moura, M.; Jardim, R.; et al. Conservation of oceanic island floras: Present and future global challenges. Perspect. Plant Ecol. 2010, 12, 107-129. [CrossRef]

33. Romeiras, M.M.; Duarte, M.C.; Santos-Guerra, A.; Carine, M.; Francisco-Ortega, J. Botanical exploration of the Cape Verde Islands: From the pre-Linnaean records and collections to late 18th century floristic accounts and expeditions. Taxon 2014, 63, 625-640. [CrossRef]

34. Romeiras, M.M.; Catarino, S.; Gomes, I.; Fernandes, C.; Costa, J.C.; Caujapé-Castells, J.; Duarte, M.C. IUCN Red List assessment of the Cape Verde endemic flora: Towards a Global Strategy for Plant Conservation in Macaronesia. Bot. J. Linn. Soc. 2016, 180, 413-425. [CrossRef]

35. Rico, L.; Duarte, M.C.; Romeiras, M.M.; Santos-Guerra, A.; Nepi, C.; Francisco-Ortega, J.; Joseph, D. Hooker's 1839 Cabo Verde Collections. Curtis's Bot. Mag. 2017, 34, 146-168. [CrossRef]

36. Brochmann, C.; Rustan, Ø.H.; Lobin, W.; Kilian, N. The endemic vascular plants of the Cape Verde Islands, W Africa. Sommerfeltia 1997, 24, 1-356.

37. POWO. Plants of the World Online. Royal Botanic Gardens, Kew. Available online: www. plantsoftheworldonline.org (accessed on 8 January 2020).

38. Cubas, J.; Martín-Esquivel, J.L.; Nogales, M.; Irl, S.D.; Hernández-Hernández, R.; López-Darias, M.; González-Mancebo, J.M. Contrasting effects of invasive rabbits on endemic plants driving vegetation change in a subtropical alpine insular environment. Biol. Invasions 2018, 20, 793-807. [CrossRef]

39. Irl, S.D.; Steinbauer, M.J.; Messinger, J.; Blume-Werry, G.; Palomares-Martínez, Á.; Beierkuhnlein, C.; Jentsch, A. Burned and devoured-introduced herbivores, fire, and the endemic flora of the high-elevation ecosystem on La Palma, Canary Islands. Arct. Antarct. Alp. Res. 2018, 46, 859-869. [CrossRef]

40. Burrows, J.; Burrows, S. Figs of Southern and South.-Central Africa; Umdaus Press: Hatfield, South Africa, 2003. 
41. Esler, K.J.; Milton, S.; Dean, W.R.J. Karoo Veld: Ecology and Management; Briza Publications: Pretoria, South Africa, 2006; p. 214.

42. Andrus, N.; Trusty, J.; Santos-Guerra, A.; Jansen, R.K.; Francisco-Ortega, J. Using molecular phylogenies to test phytogeographical links between East/South Africa-Southern Arabia and the Macaronesian islands-A review, and the case of Vierea and Pulicaria section Vieraeopsis (Asteraceae). Taxon 2004, 53, 333-346. [CrossRef]

43. Sanmartin, I.; Anderson, C.L.; Alarcon, M.; Ronquist, F.; Aldasoro, J.J. Bayesian island biogeography in a continental setting: The Rand Flora case. Biol. Lett. 2010, 6, 703-707. [CrossRef]

44. Mairal, M.; Sanmartín, I.; Herrero, A.; Pokorny, L.; Vargas, P.; Aldasoro, J.; Alarcón, M. Geographic barriers and Pleistocene climate change shaped patterns of genetic variation in the Eastern Afromontane biodiversity hotspot. Sci. Rep. 2017, 7, 45749. [CrossRef]

45. Wood, P.J. The Botany and Distribution of Faidherbia albida. In Faidherbia albida in the West African Semi-Arid Tropics; Vandenbeldt, R.J., Ed.; International Centre for Research in Agroforestry: Niamey, Niger, 1992.

46. Joly, H. The Genetics of Acacia albida (syn. Faidherbia albida). In Faidherbia albida in the West African Semi-Arid Tropics; Vandenbeldt, R.J., Ed.; International Centre for Research in Agroforestry: Niamey, Niger, 1992.albida). In Faidherbia albida in the West African Semi-Arid Tropics; Vandenbeldt, R.J., Ed.; International Centre for Research in Agroforestry: Niamey, Niger, 1992; Vandenbeldt, R.J., Ed.

47. Roupsard, O.; Ferhi, A.; Granier, A.; Pallo, F.; Depommier, D.; Mallet, B.; Joly, H.I.; Dreyer, E. Reverse phenology and dry season water uptake by Fadherbia albida (Del.) A. Chev. in an agroforestry parkland of Sudanense Africa. Funct. Ecol. 1999, 13, 460-472. [CrossRef]

48. Kirmse, R.; Norton, B. The potential of Acacia albida for desertification control and increased productivity in Chad. Biol. Conserv. 1984, 29, 121-141. [CrossRef]

49. Chevalier, A. Les Iles du Cap Vert. Géographie, biogéographie, agriculture. Flore de l'archipel. Rev. Bot. Appl. Agric. Trop. 1935, 15, 733-1090. [CrossRef]

50. Schulz, E.; Abichou, A.; Adamou, A.; Ousseïni, I.; Ballouche, A. The desert in the Sahara. Transitions and boundaries. In Palaeoecology of Africa and the Surrounding Islands; Baumhauer, R., Runge, J., Eds.; Taylor \& Francis Group: London, UK, 2009; Volume 29, pp. 63-89.

51. Steinbauer, M.J.; Field, R.; Grytnes, J.A.; Trigas, P.; Ah-Peng, C.; Attorre, F.; Beierkuhnlein, C. Topography-driven isolation, speciation and a global increase of endemism with elevation. Glob. Ecol. Biogeogr. 2016, 25, 1097-1107. [CrossRef]

52. Irl, S.D.H.; Schweiger, A.H.; Medina, F.M.; Fernández-Palacios, J.M.; Harter, D.E.; Jentsch, A.; Beierkuhnlein, C. An island view of endemic rarity-Environmental drivers and consequences for nature conservation. Divers. Distrib. 2017, 23, 1132-1142. [CrossRef]

53. Otto, R.; Whittaker, R.J.; von Gaisberg, M.; Stierstorfer, C.; Naranjo-Cigala, A.; Steinbauer, M.J.; Fernández-Palacios, J.M. Transferring and implementing the general dynamic model of oceanic island biogeography at the scale of island fragments: The roles of geological age and topography in plant diversification in the Canaries. J. Biogeogr. 2016, 43, 911-922. [CrossRef]

54. Romeiras, M.M.; Monteiro, F.; Duarte, M.C.; Schaefer, H.; Carine, M. Patterns of genetic diversity in three plant lineages endemic to the Cape Verde Islands. AoB PLANTS 2015, 7, 1-11. [CrossRef]

55. Senut, B.; Pickford, M.; Ségalen, L. Neogene desertification of Africa. C. R. Geosci. 2009, 341, 591-602. [CrossRef]

56. Adkins, J.; DeMenocal, P.; Eshel, G. The "African humid period" and the record of marine upwelling from excess 230Th in Ocean Drilling Program Hole 658C. Paleoceanography 2006, 21, 1-14. [CrossRef]

57. Pausata, F.S.R.; Messori, G.; Zhang, Q. Impacts of dust reduction on the northward expansion of the African monsoon during the Green Sahara period. Earth Planet. Sci. Lett. 2016, 434, 298-307. [CrossRef]

58. Larrasoaña, J.C.; Roberts, A.P.; Rohling, E.J. Dynamics of Green Sahara Periods and Their Role in Hominin Evolution. PLoS ONE 2013, 8, e76514. [CrossRef]

59. Jung, S.J.A.; Davies, G.R.; Ganssen, G.M.; Kroon, D. Stepwise Holocene aridification in NE Africa deduced from dust-borne radiogenic isotope records. Earth Planet. Sci. Lett. 2004, 221, 27-37. [CrossRef]

60. Kuper, R.; Kröpelin, S. Climate-Controlled Holocene Occupation in the Sahara: Motor of Africa's Evolution. Science 2006, 313, 803-807. [CrossRef] 
61. Liu, Z.; Wang, Y.; Gallimore, R.; Gasse, F.; Johnson, T.; DeMenocal, P.; Adkins, J.; Notaro, M.; Prentice, I.C.; Kutzbach, J.; et al. Simulating the transient evolution and abrupt change of Northern Africa atmosphere-ocean-terrestrial ecosystem in the Holocene. Quat. Sci. Rev. 2007, 26, 1818-1837. [CrossRef]

62. Wright, D.K. Humans as Agents in the Termination of the African Humid Period. Front. Earth Sci. 2017, 5, 4. [CrossRef]

63. Mairal, M.; Pokorny, L.; Aldasoro, J.J.; Alarcõn, M.; Sanmartín, I. Ancient vicariance and climate-driven extinction continental-wide disjunctions in Africa: The case of the Rand Flora genus Canarina (Campanulaceae). Mol. Ecol. 2015, 24, 1335-1354. [CrossRef] [PubMed]

64. Navarro-Pérez, M.L.; Vargas, P.; Fernández-Mazuecos, M.; López, J.; Valtueña, F.J.; Ortega-Olivencia, A. Multiple windows of colonization to Macaronesia by the dispersal-unspecialized Scrophularia since the Late Miocene. Perspect. Plant. Ecol. 2015, 17, 263-273. [CrossRef]

65. Dupont, L.M.; Jahns, S.; Marret, F.; Ning, S. Vegetation change in equatorial West Africa: Time-slices for the last 150 ka. Palaeogeogr. Palaeocl. 2000, 155, 95-122. [CrossRef]

66. Dalibard, M.; Popescu, S.M.; Maley, J.; Baudin, F.; Melinte-Dobrinescu, M.C.; Pittet, B.; Marsset, T.; Bernard, D.; Laurence, D.; Suc, J.P. High-resolution vegetation history of West Africa during the last $145 \mathrm{ka}$. Geobios 2014, 47, 183-198. [CrossRef]

67. Zazo, C.; Goy, J.L.; Dabrio, C.J.; Soler, V.; Hillaire-Marcel, C.; Ghaleb, B.; González-Delgado, J.A.; Bardají, T.; Cabrero, A. Quaternary marine terraces on Sal Island (Cape Verde archipelago). Quat. Sci. Rev. 2007, 26, 876-893. [CrossRef]

68. Zazo, C.; Goy, J.L.; Dabrio, C.J.; Cabero, A.; Bardaji, T.; Ghaleb, B.; Soler, V. Sea level changes during the last and present interglacials in Sal Island (Cape Verde archipelago). Glob. Planet. Chang. 2010, 72, 302-317. [CrossRef]

69. Hooghiemstra, H.; Lézine, A.-M.; Leroy, S.A.G.; Dupont, L.; Marret, F. Late Quaternary palynology in marine sediments: A synthesis of the understanding of pollen distribution patterns in the NW African setting. Quat. Int. 2006, 148, 29-44. [CrossRef]

70. Dupont, L. Orbital scale vegetation change in Africa. Quat. Sci. Rev. 2011, 30, 3589-3602. [CrossRef]

71. Figueiredo, A. Assessing Climate Change Impacts on the Distribution of Flora and Vegetation at Madeira Island. Ph.D. Thesis, Universidade de Coimbra, Coimbra, Portugal, 2013.

72. Barres, L.; Galbany-Casals, M.; Hipp, A.; Molero, J.; Vilatersana, R. Phylogeography and character evolution of Euphorbia sect. Aphyllis subsect. Macaronesicae (Euphorbiaceae). Taxon 2017, 2, 324-342. [CrossRef]

73. Romeiras, M.M.; Paulo, O.S.; Duarte, M.C.; Pina-Martins, F.; Cotrim, M.H.; Carine, M.A.; Pais, M.S. Origin and diversification of genus Echium (Boraginaceae) in Cape Verde islands: A phylogenetic study based on ITS (rDNA) and cpDNA sequences. Taxon 2011, 60, 1375-1385. [CrossRef]

74. Alarcón, M.; Roquet, C.; García-Fernández, A.; Vargas, P.; Aldasoro, J.J. Phylogenetic and phylogeographic evidence for a Pleistocene disjunction between Campanula jacobaea (Cape Verde Islands) and C. balfourii (Socotra). Mol. Phylogenet. Evol. 2013, 69, 828-836. [CrossRef] [PubMed]

75. Menezes, T.; Romeiras, M.M.; de Sequeira, M.M.; Moura, M. Phylogenetic relationships and phylogeography of relevant lineages within the complex Campanulaceae family in Macaronesia. Ecol. Evol. 2017, 1-21. [CrossRef]

76. Migliore, J.; Baumel, A.; Juin, M.; Fady, B.; Roig, A.; Duong, N.; Médail, F. Surviving in Mountain Climate Refugia: New Insights from the Genetic Diversity and Structure of the Relict Shrub Myrtus nivellei (Myrtaceae) in the Sahara Desert. PLOS ONE 2013, 8, e73795. [CrossRef]

77. Weigelt, P.; Steinbauer, M.J.; Cabral, J.S.; Kreft, H. Late Quaternary climate change shapes island biodiversity. Nature 2016, 532, 99. [CrossRef]

78. Romeiras, M.M.; Pena, A.R.; Menezes, T.; Vasconcelos, R.; Monteiro, F.; Paulo, O.S.; Moura, M. Shortcomings of Phylogenetic Studies on Recent Radiated Insular Groups: A Meta-Analysis Using Cabo Verde Biodiversity. Int. J. Mol. Sci. 2019, 20, 2782. [CrossRef]

79. Harter, D.E.; Irl, S.D.; Seo, B.; Steinbauer, M.J.; Gillespie, R.; Triantis, K.A.; Beierkuhnlein, C. Impacts of global climate change on the floras of oceanic islands-Projections, implications and current knowledge. Perspect. Plant. Ecol. Evol. Syst. 2015, 17, 160-183. [CrossRef]

80. Patiño, J.; Mateo, R.G.; Zanatta, F.; Marquet, A.; Aranda, S.C.; Borges, P.A.; Muñoz, J. Climate threat on the Macaronesian endemic bryophyte flora. Sci. Rep. 2016, 6, 29156. [CrossRef] 
81. Monteiro, F.; Fortes, A.; Ferreira, V.; Pereira Essoh, A.; Gomes, I.; Correia, A.M.; Romeiras, M.M. Current Status and Trends in Cabo Verde Agriculture. Agronomy 2020, 10, 74. [CrossRef]

82. Caujapé-Castells, J.; García-Verdugo, C.; Marrero-Rodríguez, Á.; Fernández-Palacios, J.M.; Crawford, D.J.; Mort, M.E. Island ontogenies, syngameons, and the origins and evolution of genetic diversity in the Canarian endemic flora. Perspect. Plant. Ecol. 2017, 27, 9-22. [CrossRef]

83. Fernández-Palacios, J.M.; Arévalo, J.R.; Balguerías, E.; Barone, R.; Nascimento, L.; de Elias, R.B.; Delgado, J.D.; Fernández-Lugo, S.; Méndez, J.; Naranjo Cigala, A.; et al. La Laurisilva. Canarias, Madeira y Azores; Macaronesia Editorial: Santa Cruz de Tenerife, Spain, 2017.

84. Castilla-Beltrán, A.; Duarte, I.; de Nascimento, L.; Fernández-Palacios, J.M.; Romeiras, M.; Whittaker, R.J.; Jambrina-Enríquezf, M.; Mallolf, C.; Cundyg, A.B.; Edwardsa, M.; et al. Using multiple palaeoecological indicators to guide biodiversity conservation in tropical dry islands: The case of São Nicolau, Cabo Verde. Biol. Conserv. 2020, 242, 108397. [CrossRef]

85. Freitas, R.; Romeiras, M.; Silva, L.; Cordeiro, R.; Madeira, P.; González, J.A.; Wirtz, P.; Falcón, J.M.; Brito, A.; Floeter, S.R.; et al. Restructuring of the 'Macaronesia' biogeographic unit: A marine multi-taxon biogeographical approach. Sci. Rep. 2019, 9, 15792. [CrossRef] [PubMed]

(C) 2020 by the authors. Licensee MDPI, Basel, Switzerland. This article is an open access article distributed under the terms and conditions of the Creative Commons Attribution (CC BY) license (http://creativecommons.org/licenses/by/4.0/). 